\title{
Contribution of poisonous plants in herbal remedies
}

\author{
Surekha D. Salgar, Md. Rageeb Md. Usman, Gautam P. Vadnere, Santram Lodhi, Kranti D. Patil \\ Department of Pharmacognosy, Smt. S. S. Patil College of Pharmacy, Chopda, Maharshtra, India
}

\begin{abstract}
The aim of this study concludes that toxic medicinal plants have some medicinal values. Certain precautions about those plants are enough to use these toxic plants as medication purpose. Since plant toxins show many useful effects, they can be used in treating respective diseases. They can be modified to show better affinity and efficacy. Poisonous, medicinal plants are used for various ailments. This study reveals that wide numbers of phytochemical constituents have been reported from various medicinal plants which possess pharmacological activities, herbal remedies, and other important medicinal properties. This information is the most important for pharmaceutical companies could formulate drug.
\end{abstract}

Correspondence:
Surekha D. Salgar, Department of

Pharmacognosy, Smt. S. S. Patil College of

Pharmacy, Chopda, Maharshtra, India.

E-mail: surekhayamgar@gmail.com

Keywords: Toxic medicinal, poisonous medicinal plants, herbs, formulate drug and medicinal properties

\section{Introduction}

In India, the use of the different parts of several medicinal plants to cure specific ailments has been in vogue from ancient times. The indigenous system of medicine, namely, Ayurvedic, Siddha, and Unani has been in existence for several centuries. In Siddha medicinal system use of poisonous plants helps to cure some disease. It is important to have an awareness regarding the poisonous plants which when used in the proper, prescribed dose, acts as potent therapeutics agents. According to the World Health Organization, $80 \%$ of the population of developing countries depends on plant drugs for a regular source of medicines. Poisonous principles are classified based on the chemistry of toxic compounds present in it: Alkaloids, glycosides, oxalates, photosensitizing compounds, phytotoxins, polypeptides and resins. ${ }^{[1]}$

There are several species which are poisonous or injurious to human body and can be found in the garden or planted by the forest department as a roadside tree with or without the knowledge about their effects on human body system. Poisoning can be by contact causing skin irritation, ingestion causing internal poisoning and absorption. Some plants which are considered as harmless are actually

\section{Access this article online}

Website: http://www.jpbs-online.com DOI: 10.31555/jpbs/2018/6/2/18-35

E-ISSN: $2321-0125$

How to cite this article: Salgar SD, Usman RMd, Vadnere GP, Lodhi S, Patil KD. Contribution of poisonous plants in herbal remedies. J Pharm BioSci 2018;6(2):18-35.

Source of Support: Nil, Conflict of Interest: None declared. not so. Many plants are used in some way or the other in medicines especially in homeopathic pharmacology. ${ }^{[2]}$

\section{Classification of Poison}

According to their mode of action, poisons are broadly classified into three groups; these three broad groups are sub-divided on the basis of their effect on the body, type of composition, etc., which are available in the literature ${ }^{[3-5]}$ and summarized as shown in Figure 1.

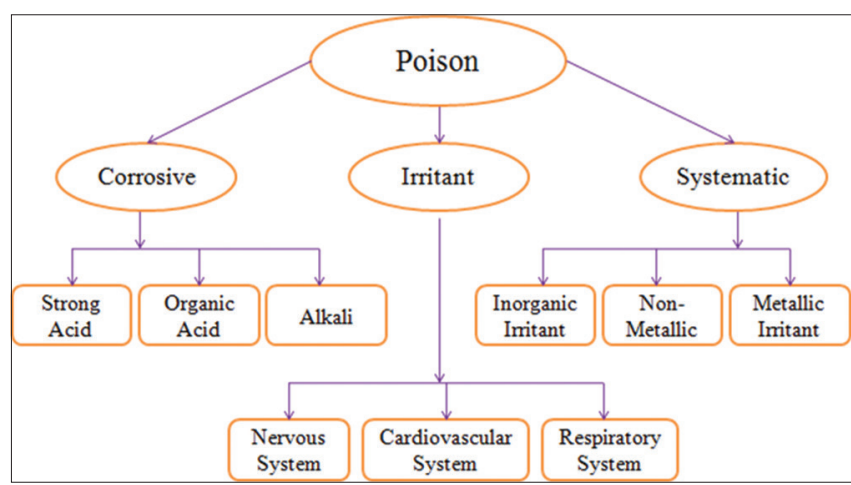

Figure 1:Types of poison in clinical point of view

\section{Classification}

Plant toxins are classified based on their structural and chemical properties. They are grouped into alkaloids, glycosides, tannins, proteins, oxalates, enzyme inhibitors, antivitamins, phytoestrogens, volatile etheric layers, and photosensitizing substances. ${ }^{[1,5-8]}$

- Alkaloids include indole alkaloids, pyrrolizidine alkaloids, tropane alkaloids, opium alkaloids, vicine and covicine alkaloids. 
- Glycosidal toxins include cardiac glycosides, goitrogenic glycosides, anthraquinone glycosides, mustard oil glycosides, saponin glycosides, and cyanogenetic glycosides.

- Tannins like pyrogallol.

- Proteins such as lectin, abrin, ricin, cicutoxin, anisatin, gelonin, falcarinol, and oenotheatoxin.

- Antivitamins like thiaminases, phytoestrogens like coumestrol. Volatile etheric layers such as ushuriol, photo sensitizing substances including hypericin.

- Enzyme inhibitors such as cholinesterase inhibitors, protease inhibitors, amylase inhibitors. Others include lathyrogens, antithiamine compounds, and avidin.

\section{Plant toxins $^{[9-13]}$}

- Abrin, anisatin, andromedotoxin, apocyanin, amygdalin, aesculin, anabasine, anagyrine, aspargine, avidin

- Brucine

- Chaconine, cicutoxin, cicutiol, cardinilides, cycasin, cyanarin, confoline, convolmine, covicine

- Convoline, convosine, caratotoxin, cucurbitacin

- Delphinine, djenkolic acid, dhurrin, levo-duboisine

- Epipodophyllotoxin

- Falcarinol, frascin, fagopyrin quinines, furocoumarin

- Gelonin, gossypol, grayanotoxin, gallotoxin

- Hymexon, hypericin, hymenoxon, hyoscine

- Illicin, isoalyl thiocyanates, ipomeamarone

- Linamarin, lotaustralin, lycorine, laetrile, lectin, lantanene

- Beta-methylamino-l-alanine, macrozamin, mezeein, 4-methoxypyridoxine

- Nitrates, naudicoline, nerosides

- Oenanthotoxin

- Phytotoxin, pseudaconitine, pyrrolizidine alkaloid, persin, prunassin, podopyllotoxin, phenanthridineprolamine, phytolaccine, phytolaccatoxin, phytolaccigenin, protoanemonin

- Resiniferatoxin, ricin, ranunculin

- Saponin, scopolamine, solamargine, solasodamine, solasodine, solasonine, solauricidine, solauricine, strychnine, swainsonine, syringomycin, sambunigrin, solanine and shankhapushpin

- Thionins, tinyatoxin, tutin, tremetol, taxine

- Ushuriol

- Vicine.

Plant toxins act on all parts of the body with some common symptoms such as vomiting and nausea. They show actions based on the way of exposure and concentration. They are both useful and harmful.

\section{Characteristics of Ideal Poison}

The characters of an ideal homicidal/suicidal poison should be:

- Cheap

- Easily available

- Colourless

- Odorless and tasteless

- Capable of being administered, either in food, drink or medicine, without producing any obvious change to prevent suspicion and highly toxic
- Capable of painless death

- Signs and symptoms should resemble a natural disease, or the serious ill effects should be delayed sufficiently long for the accused to escape suspicion

- Must be rapidly destroyed or made undetectable in the body.

The number of factors, which are affecting the characteristics of poisoning any victim's as dose/ quantity given to the victim, in which form (physical/ chemical) the poison inject to the body, resistivity of body and condition of the victim (he/she might be drug addict/in sleep or intoxication) (Table 1).

\section{Treatments $^{[14]}$}

\section{General first aid}

When a child eats any non-food plant material, contact a physician or a poison control center whether symptoms are present or not. If a poisonous plant has been eaten and if medical help is not readily available, the U.S. Department of Health and Human Services, Division of Poison Control suggests the following: Vomiting should be induced (unless the victim is already vomiting, is unconscious or convulsing) by giving syrup of Ipecac with a glass of water. To prevent the vomit us from being inhaled (aspirated) into the lungs the victim should be made to walk about, or should be held in a head down "spanking position." After vomiting has ceased,w about 1ounce (child; 3 oz. adult) of activated charcoal and water should be given orally. Because activated charcoal will not dissolve in water, it should be swirled around in the glass and drunk quickly. Many pediatricians recommend that syrup of ipecac and activated charcoal be kept in the home medicine chest. If the child must be brought to a physician or emergency room, a sample of the plant, with flowers and seeds if possible, should be brought along for positive identification (Table 2).

\section{Thevetia peruviana}

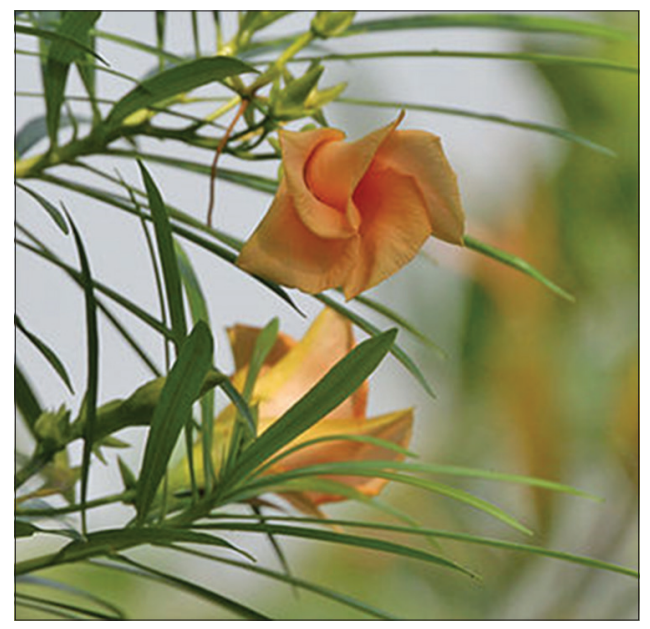

Figure 2: Thevetia peruviana

\section{Biological source}

Cacabela thevetia is an evergreen tropical shrub or small tree. Its leaves are willow-like, linear-lanceolate and glossy green in color.

Family: Apocynaceae. 


\section{Chemical constituent}

Plant contains milky latex and a number of cardioactive glycosides. Seed kernel contains a phytosterolin, glucosides.

\section{Medicinal uses}

- It is used as a heart stimulant but in it natural form its extremely poisonous.

- These cardenolides are not destroyed by drying or heating, and they are very similar to digoxin from digitalis purpurea.

\section{Mode of action}

Inhibit sodium potassium adenosine triphosphate (ATP) base.

- Increase intracellular sodium and serum potassium.

- Negative chronotropic, positive inatropic effects.

\section{Treatment of poisoning}

- Induce emesis at home (ipecac).

- Gastric lavage within $1 \mathrm{~h}$ or activated charcoal.

- Cardiac pacing for third-degree heart block.

\section{Herbal remedies}

- A bark or leaf decoction is taken to loosen the bowels, as an emetic, and is said to be an effective cure for intermittent fevers.

- In Senegal water in which leaves and bark were macerated is taken to cure amenorrhea.

- The latex is applied to soften corns and calluses (Figure 2). ${ }^{[15]}$

\section{Datura metel}

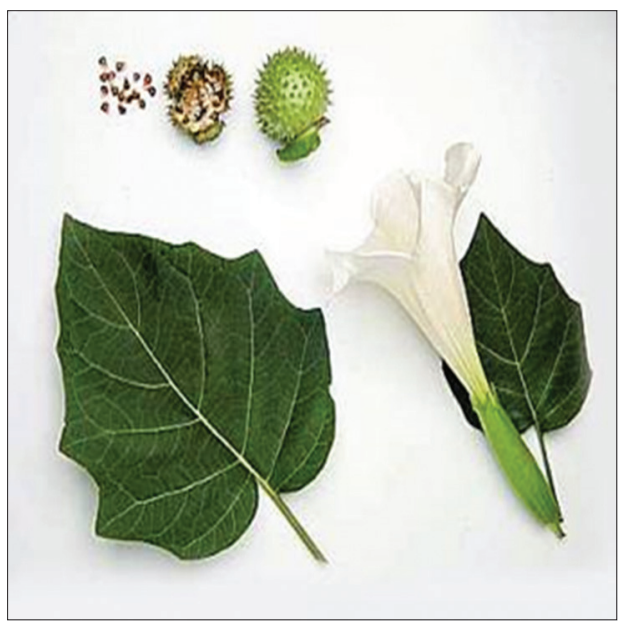

Figure 3: Datura metel

\section{Biological source}

D. metel is a shrub-like perennial herb, commonly known as devil's trumpet and metel.

Family: Solanaceae.

\section{Chemical constituent}

Principal constituents of the plant are a large number of tropane alkaloids including hyoscyamine, hyoscine, and littorine.

\section{Medicinal uses}

Smoking blends of datura and cannabis are used as smoke because it is not ruthless and burns easier. It has been used by the British soldiers to treat respiratory problems. Both scopolamine and atropine are used as sedatives and sometimes helps in curing of motion sickness, nausea, and dizziness.

\section{Mode of action}

It stimulates the central nervous system (CNS) and simultaneously depresses peripheral nerves and dilates the pupils by peripheral action.

\section{Treatment of poisoning}

- Ipecac to induce emesis or gastric lavage.

- Activated charcoal to reduce absorption of toxic substances.

- Diazepam for hallucination and delirium.

\section{Herbal remedies}

- Seeds or powered datura leaves are part of the traditional medicine of Indochina and Africa. Datura is often mixed with cannabis, and this mixture is smoked to relieve asthma and rheumatism.

- In Mexico, it was taken by women to relieve the pain of childbirth. The seeds are added to wine and beer to increase intoxication.

- Flowers and seed of Datura were used to treat skin eruptions, colds, and nervous disorders. It was mixed with cannabis in wine to use as a narcotic for surgical procedures (Figure 3). ${ }^{[16]}$

\section{Abrus precatorius}

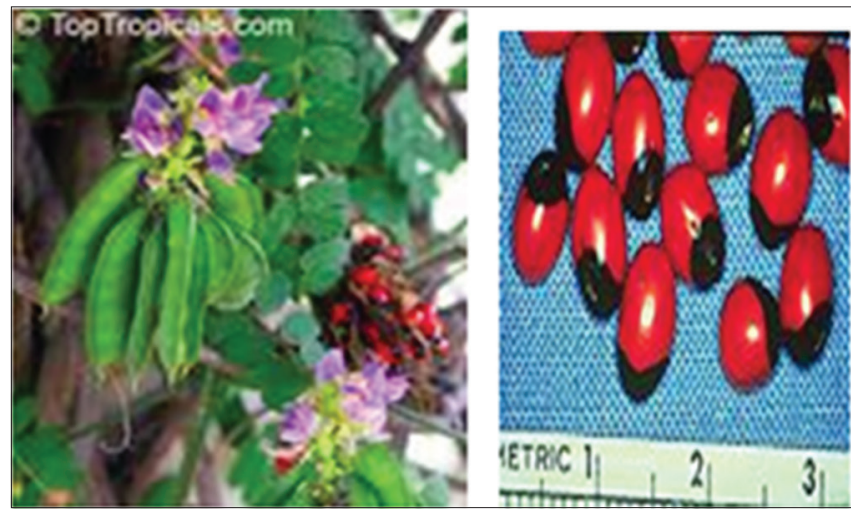

Figure 4: Abrus precatorius

\section{Biological source}

A. precatorius is a slender, perennial climber that twines around trees, shrubs, and hedges. It is a legume with long, pinnate-leafleted leaves.

Family: Fabaceae. 


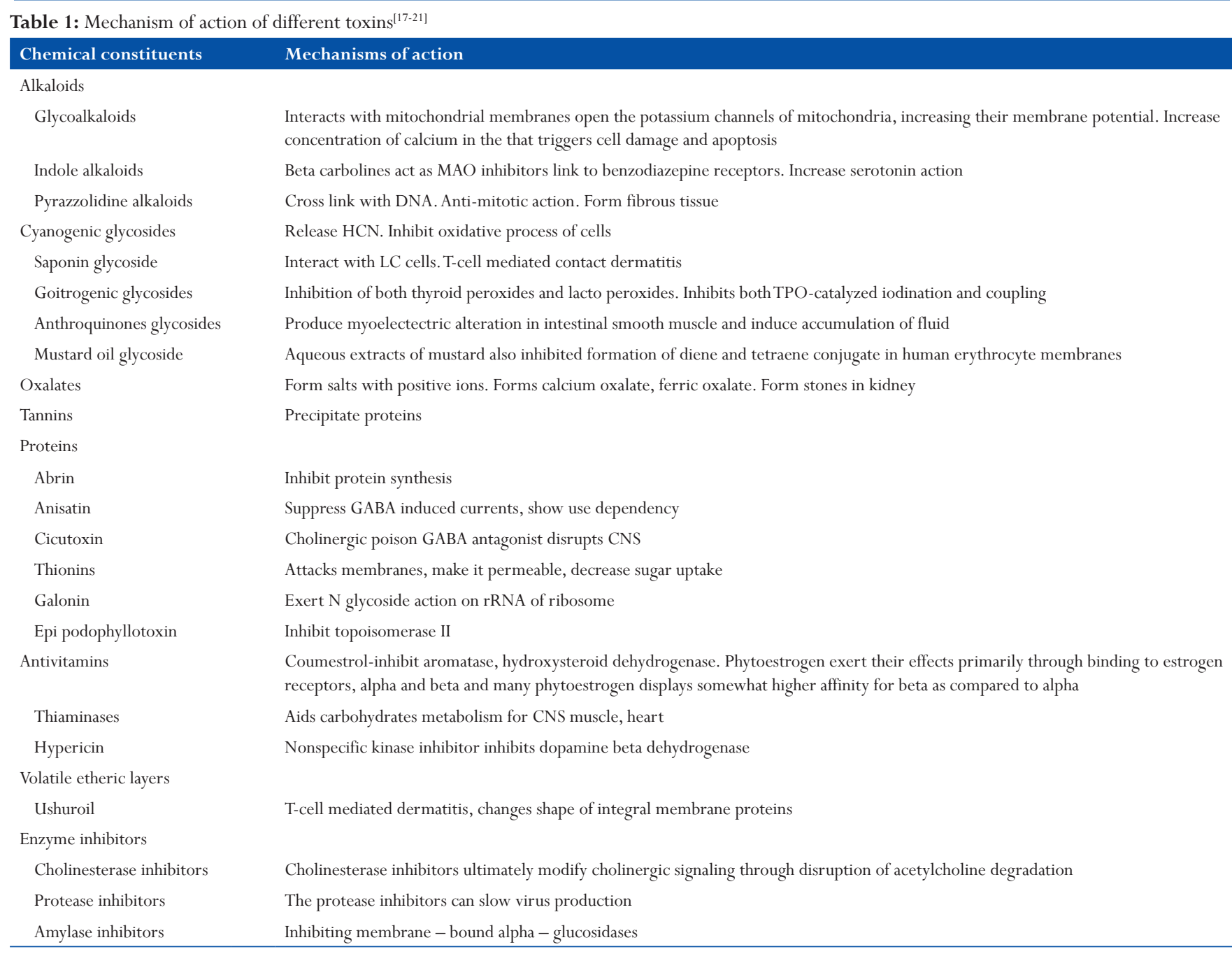

MAO: Monoamine oxidase, HCN: Hydrogen cyanide, LC: Langerhans cell, TPO: Thyroid peroxidase, GABA: Gamma-aminobutyric acid, CNS: Central nervous system

\section{Chemical constituent}

A. precatorius L. is commonly known as. It principally contains flavonoids, triterpene glycosides, abrin and alkaloids.

\section{Medicinal uses}

- A tea is made from leaves and use to treat fevers cough and colds

- A plant is also used in traditional medicine to treat scratches and sores wound caused by dog, cat, and mice.

\section{Mode of action}

- Abrin exerts it toxic action by itself to the cell membrane

- It has a direct action on parenchymal (e.g., liver and kidney cells) red blood cells.

\section{Treatment of poisoning}

Administration of fluid and electrolytes will alleviate dehydration.

\section{Herbal remedies}

Purified Gunja seed powder is made a paste with water, applied externally to relieve joint pains, swelling, sciatica pain, and cervical spondylosis related pain. This paste is applied over hairless patches of alopecia areata to regrow hair (Figure 4). ${ }^{[22]}$

\section{Myristica fragrans}

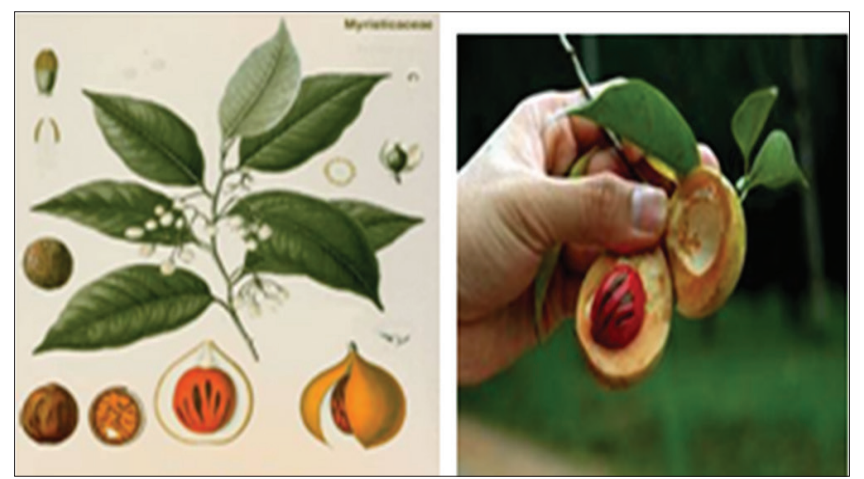

Figure 5: Myristica fragrans

\section{Biological source}

Nutmeg consists of dried kernels of the seeds of $M$. fragrans houtt.

Family: Myristicaceae. 


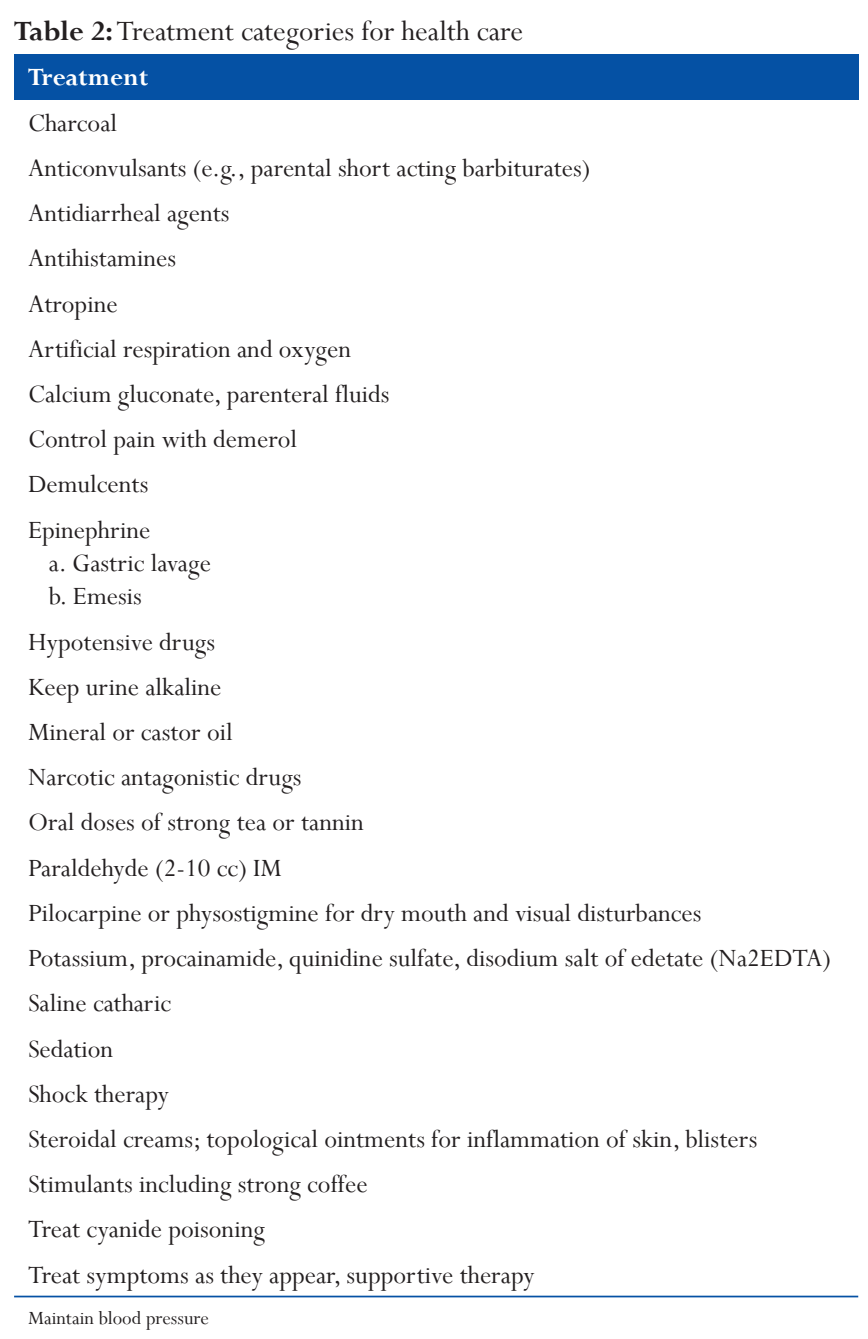

\section{Chemical constituent}

Nutmeg contains $5-16 \%$ of volatile oil, and about $30 \%$ of fat. The volatile oil contains about 4-8\% myristicin, elimicin and safrole.

\section{Medicinal uses}

- $\quad$ Since ancient times, nutmeg and its oil were being used in Chinese and Indian traditional medicines for illnesses related to the nervous and digestive systems

- Nutmeg oil contains eugenol, which has been used in dentistry for toothache relief.

\section{Mode of action}

- Elemicin undergoes oxidation of its oleficin side chain to produce 3,4, 5trimethoxyamphetamine (TMA) a psychotropic drug agent.

- Myristicin produces MMDA which is metabolized to form TAM. MMDA has a higher potency than TAM.

\section{Treatment of poisoning}

- $\quad$ Symptomatic and supportive

- Induce emesis (with ipecac) or gastric levage
- Activated charcoal

- Diazepam for restlessness or hallucinations.

\section{Herbal remedies}

- Its paste is applied over forehead to relieve headache and over painful joints to relieve pain

- Used in throat disorders and to improve voice quality. It helps to clear the throat of excess sputum

- Its oil is applied externally over the penis as a remedy for erectile dysfunction (Figure 5). ${ }^{[23,24]}$

\section{Strychnos nux-vomica}

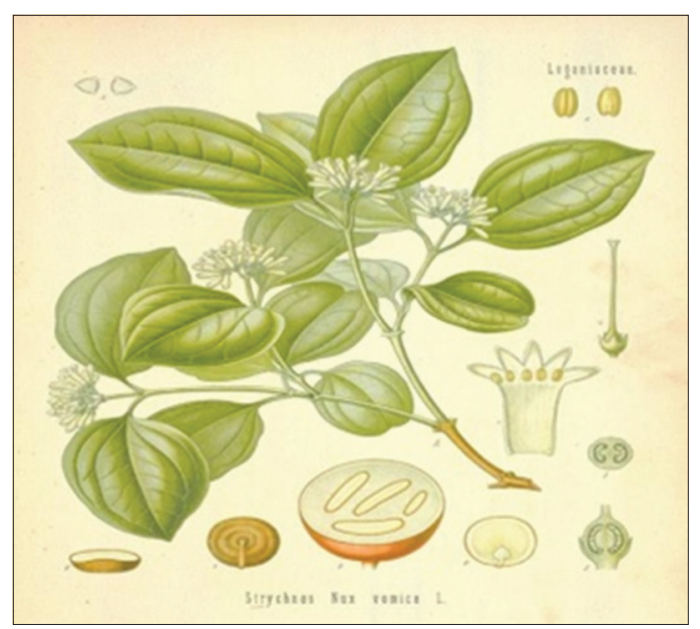

Figure 6: Strychnos nux-vomica

\section{Biological source}

It consists of dried ripe seeds of S. nux-vomica, Linn. containing not less than $1.2 \%$ strychnine.

Family: Loganiaceae.

\section{Chemical constituent}

Alkaloids (2.5-5\%): Strychnine, strychnicine, brucine, etc., glycoside, loganin, fixed oil (2-4\%) and proteins.

\section{Medicinal uses}

Nux vomica is recommended for upset stomach, vomiting, abdominal pain, constipation, intestinal irritation, hangovers.

\section{Mode of action}

- Strychnine is a potent convulsant. It cause's increased reflex excitability in the spinal cord

- Brucine resembles strychnine activity but it is less potent.

\section{Treatment of poisoning}

- Activated charcoal

- Support respiratory and cardiovascular functions

- Intubation with suxamethonium chloride may be necessary. 


\section{Herbal remedies}

- It is also useful to reduce pimples, acne and used for skin care

- The powdered seed is also useful in tonic dyspepsia

- It is used for treating abdominal pain and vomiting

- The powdered seeds are also recommended for treatment of liver cancer ${ }^{[25,26]}$ (Figure 6).

\section{Alocasia macrorrhizos}

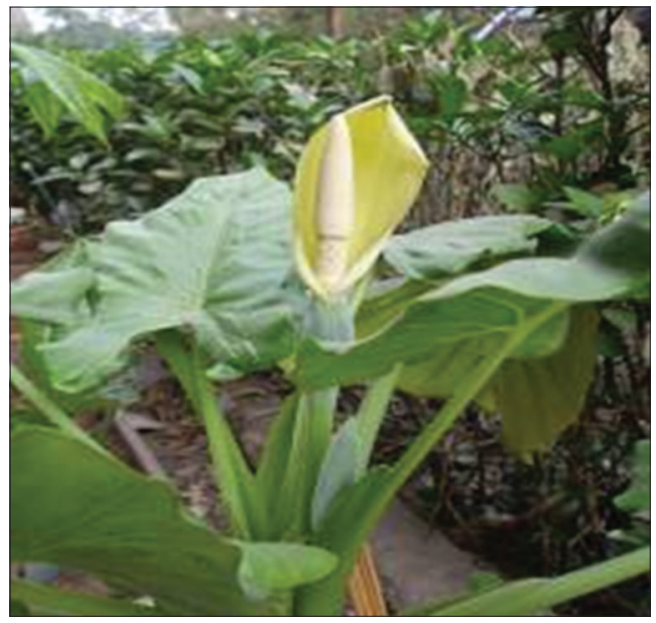

Figure 7: Alocasia macrorrhizos

\section{Biological source}

A. macrorrhizos is a species of flowering plant in the arum.

Family: Araceae.

\section{Chemical constituent}

Plant yields flavonoids, cynogenetic glycosides, ascorbic acid, gallic acid, mallic acid, oxalic acid, alocasin, amino acids, succinic acid, and B-lectins. Rhizomes contain phytosterols, alkaloids, glucose, and fructose.

\section{Medicinal uses}

Medicinally, the juice from freshly cut stems was used on the skin as an antidote after touching itchy or stinging plants such as KO (sugar cane) and nettle.

\section{Mode of action}

When the plant is chewed the sharp crystals injure the mucous membrane allowing toxic proteins to penetrate.

\section{Treatment of poisoning}

- Wipe out the mouth with a cold. Wet cloth and give milk to drink.

- Antihistamines, mouthwashes, antiseptics, and steroids may be used.

\section{Herbal remedies}

- The steamed oiled leaves can help relieve rheumatic pains by applied around painful joints overnight.

- $\quad$ Powdered leave speed up wound healing.

- Underground stem of this plant is a common domestic remedy in gout and rheumatism. A formula called manmanda is prepared for treatment of gout, and rheumatism (Figure 7). ${ }^{[27,28]}$

\section{Glorisa superba}

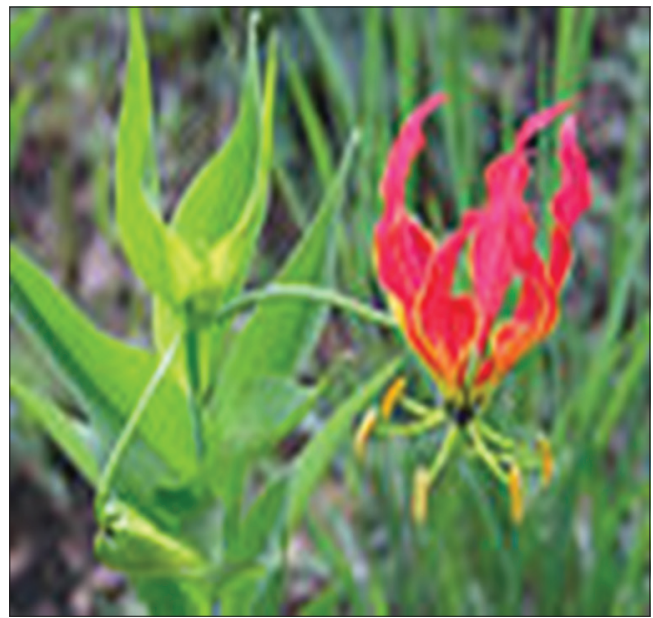

Figure 8: Glorisa superba

\section{Biological source}

G. superba is a species of flowering plant.

Family: Colchicaceae.

\section{Chemical constituent}

Rhizomes and seeds contain colchicine isoperlolyrine and related tropolane alkaloids. Air dried rhizomes contain $B$-sitosterol and its glycoside, 2-hydroxy 6-methoxy benzoic acid.

\section{Medicinal uses}

- It cures skin diseases and itching in the skin.

- It gives comfort from abdominal pain.

- It is also used in the treatment of piles and chronic ulcer.

- The extract from the root is used as a tonic that can add vigor to the body.

\section{Mode of action}

- Colchicine has an antimitotic effect.

- It stops cell division by disrupting the spindle apparatus during the metaphase.

- It can alter neuromuscular function.

\section{Treatment of poisoning}

- Hospitalize the patient immediately. 
- Induce vomitting (ipecac)/gastric lavage.

- Give repeated activated charcoal.

\section{Herbal remedies}

- The extracts from the plant can act as pesticides and so are useful in agriculture.

- In Tamil Nadu, the root juice is given as a cooling medicine for the treatment of gonorrhea as healers mix juice from the root into fresh goat's milk (Figure 8). ${ }^{[29,30]}$

\section{Ricinus communis}
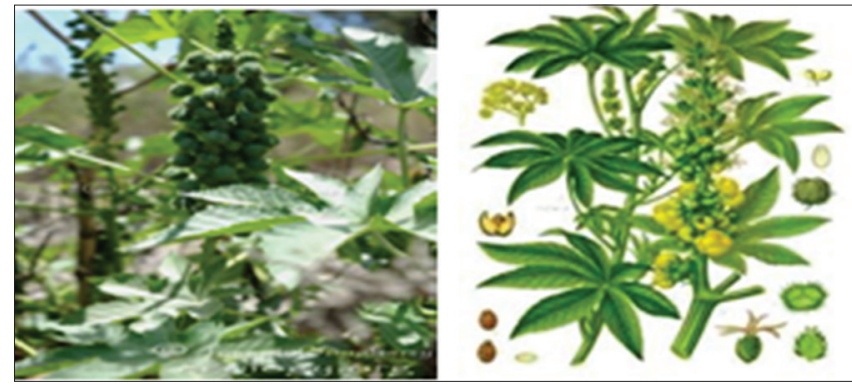

Figure 9: Ricinus communis

\section{Biological source}

R. communis, the castorbean or castor-oil-plant, is a species of flowering plant in the spurge.

Family: Euphorbiaceae.

\section{Chemical constituent}

The oil principally consists of glycerides of ricinoleic, isoricinolic, stearic and dihydroxystearic acids, free ricinoleic, isoricinolic, stearic, linoleic.

\section{Medicinal uses}

- The oil and seed of castor bean have been used as folk remedies for: Warts, cold tumors, indurations of the abdominal organs.

- $\quad$ Seed oil is purgative.

- Leaf-paste is used as poultice on sores, gout or rheumatic swellings.

\section{Mode of action}

Ricin impairs chain elongation in protein synthesis, causing cell death and tissue damage.

\section{Treatment of poisoning}

- Induce emesis at home (ipecac).

- Immediate gastric lavage or activated charcoal.

- Correct fluid and electrolyte imbalance immediately.

\section{Herbal remedies}

- Castor leaf is dipped sesame oil and heated till it becomes hot. This is applied over blunt injuries, arthritis, painful joints to relieve pain.
- Castor oil leaf and root is made paste with sesame oil or castor oil, slightly heated and applied externally to relieve migraine, low back ache, sciatica pain, arthritis pain, mastitis and skin disorders associated with pain (Figure 9). ${ }^{[31]}$

\section{Manihot utilissima}

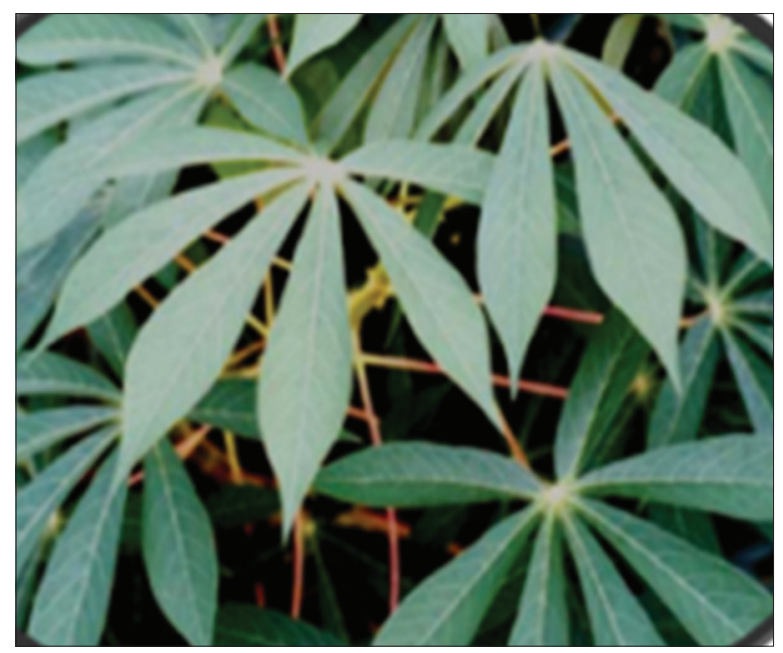

Figure 10: Manihot utilissima

\section{Biological source}

The fecula of the root of M. utilissima, Pohl (Jatropha Manihot, Linné; Janipha Manihot, Kunth).

Family: Ephorbiaceae.

\section{Chemical constituent}

The root of M. utilissima to be composed of starch (13.63\%), water $(61.7 \%)$, lignin $(23.49 \%)$, and ash (1.18\%).

\section{Medicinal uses}

- Cassava root has been promoted as a treatment for bladder and prostate cancer.

- According to the American Cancer Society, "there is no conviction scientific evidence that cassava or tapioca is effective in preventing or treating cancer."

\section{Mode of action}

- A large sudden does hydrogen cyanide is highly poisonous to all humans and animals because it rapidly inactivates cellular respiration thereby causing death.

- This means that it stops cells from being able to use oxygen.

\section{Treatment of poisoning}

There is no known treatment for cynide poisoning. Treatment with sodium thiosulphate ( $\mathrm{Na} 2 \mathrm{~S} 2 \mathrm{O} 3$ ) a cynide antidote, gove disappointing results. A good and varied diet, high does multivitamins, and physical rehabitation are advised. 


\section{Herbal remedies}

- The root of the plant is also used to make tapioca, a starch found in puddings and other foods.

- The roots of the cassava are applied directly to the skin (often in the form of a poultice) to promote the healing of wounds and sores.

- Cassava root starch is sometimes used as an ingredient in vitamin C supplements (Figure 10). ${ }^{[32,33]}$

\section{Peganum harmala}

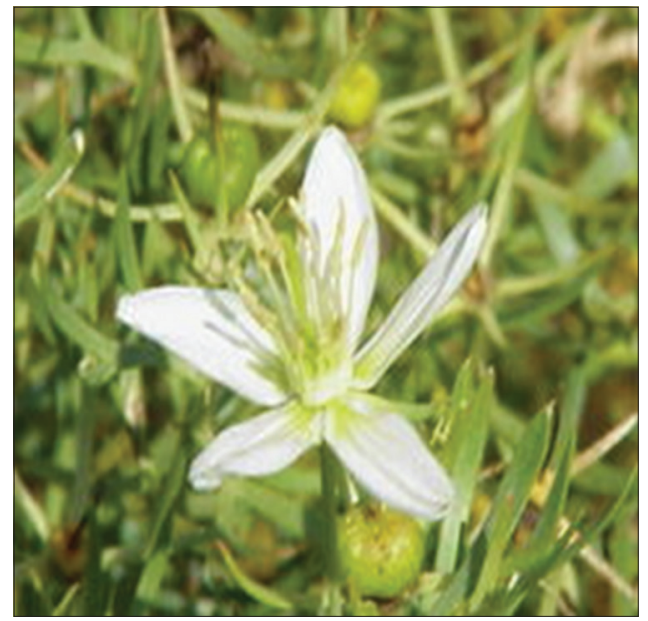

Figure 11: Peganum harmala

\section{Biological source}

P. harmala, Wild Rue commonly called Harmal.

Family: Nitrariaceae.

\section{Chemical constituent}

The harmala alkaloids occur in P. harmala in concentrations of roughly $3 \%$, though tests have documented anywhere from $2 \%$ to $7 \%$ or even higher, as natural sources tend to vary widely in chemical makeup.

\section{Medicinal uses}

- Harmal is used as an analgesic and anti-inflammatory agent.

- In Yemen, it was used to treat depression and it has been established in the laboratory that harmaline, an active ingredient in Peganum harmal.

- It is a CNS stimulant and a "reversible inhibitor of monoamine oxidase-A," a category of antidepressant.

\section{Mode of action}

- Harmaline is a reversible monoamine oxidase inhibitor found especially in higher quantities in ripe seed.

- The plant also has antibacterial, antioxidant, anti-inflammatory and antitumor activity.

\section{Treatment of poisoning}

Supportive therapy:

- IV fluids.

- Antacids (or H2 antagonist).

\section{Herbal remedies}

- Small quantity of the seeds in 30 times as much water of grape juice and boil to a quarter and drink each day $10 \mathrm{~g}$ for 30 days, it would have an undeniable effect for hysteria.

- Seeds accompany with flax seed and honey is prescribed for asthma.

- Who are addicted to drug can roast seeds and then pound them with honey for cure (Figure 11). ${ }^{[3]}$

\section{Adenia palmate}

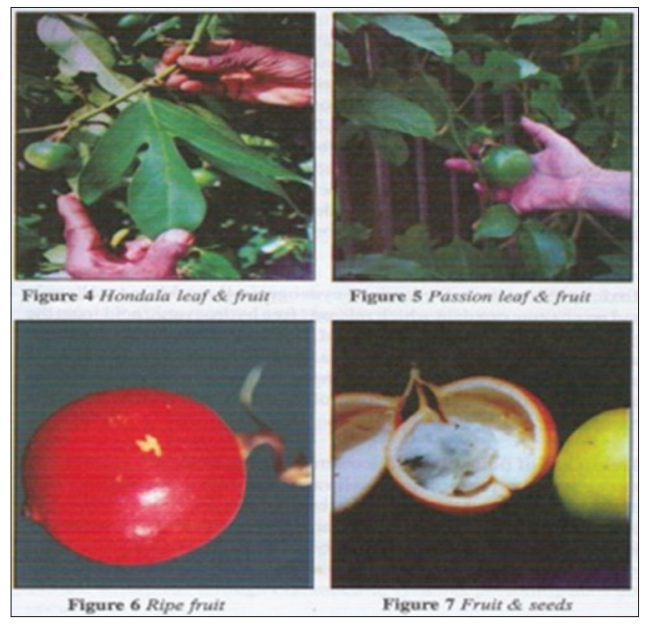

Figure 12: Adenia palmate

\section{Biological source}

A. chinensis is a genus of flowering plants in the passionflower.

Family: Passifloraceae.

\section{Chemical constituent}

The major chemical substances of interest in the survey have been the alkaloids and steroidal sapogenins however other diverse groups are naturally occurring phytochemicals such as flavonoids, tannins, unsaturated sterols, terpenoids, and essential oils.

\section{Medicinal uses}

- Cissampeloides are used to treat many conditions, including gastrointestinals, inflammation, pain, fever, malaria, leprosy, scabies, cholera, anemia, bronchitis, sexually transmitted diseases, menorrhagia, and mental illness.

- It is used both as an abortifacientand to prevent miscarriage. The leaves of Adenia tricostata are used to treat fever. 


\section{Mode of action}

- $\quad$ First phase-hydrocynide acid.

- Second phase-local toxalbumin effects.

- Third phase-hypersensitivity reaction.

\section{Treatment of poisoning}

- If no vomiting occurs induce emesis with ipecac syrup or perform gastric levage.

- Activated charcoal will help the absorption of toxic substances.

- IV fluid therapy may be needed.

\section{Herbal remedies}

- The crushed stems are thrown into water to act as a fish poison.

- The leaves, branches, bark, wood, and roots may be used in fish or arrow poisons.

- An infusion of the root and leaves is drunk and the powdered root and leaves eaten in porridge, to prevent a threatened abortion.

- An infusion of the leaf is used as a stimulant to treat depression and insanity (Figure 12). ${ }^{[35,36]}$

\section{Nicotiana tobacum}

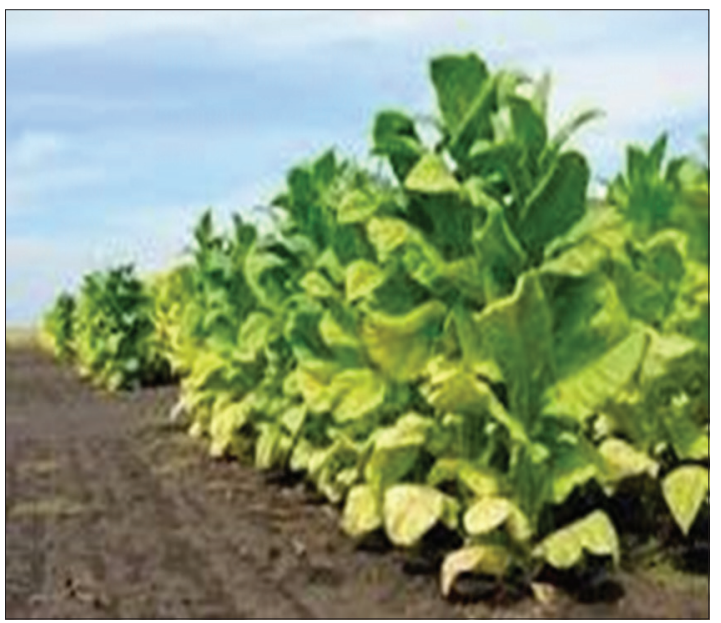

Figure 13: Nicotiana tobacum

\section{Biological source}

N. tabacum, or cultivated tobacco, is an annually-grown herbaceous plant.

Family: Solanaceae.

\section{Chemical constituent}

Leaves contain active principles, the toxic alkaloid nicotine (0.6-9\%) and three other alkaloids: Nicoteine, nicotelline, and nicotinine. Also yields anabasine.

\section{Medicinal uses}

- In Europe, first reported as a remedy for wound healing and headaches.
- Reported as curative for skin ailmentsw, goiter, broken limes, headaches, ulcers, worms, syphilis, and dropsy.

\section{Mode of action}

- Nicotine binds stereo especially to acetylcholine receptors at autonomic ganglia, the adrenal medulla, the neuromuscular junction, and the brain.

- This evokes the release of catecholamine.

\section{Treatment of poisoning}

- Induced emesis (ipecac) or gastric levage and activated charcoal.

- Supportive therapy directed towards maintaining respiration and blood pressure (intravenous fluid) and controlling convulsions.

\section{Herbal remedies}

- A wet tobacco leaf applied to piles is a certain cure. The inspissated juice cures facial neuralgia if rubbed along the tracks of the affected nerve.

- Externally nicotine is an antiseptic. It is eliminated partly by the lungs, but chiefly in the urine, the secretion of which it increases.

- Formerly tobacco in the form of an enema of the leaves was used to relax muscular spasms, to facilitate the reduction of dislocations (Figure 13). ${ }^{[37]}$

\section{Pagiantha dichotoma}

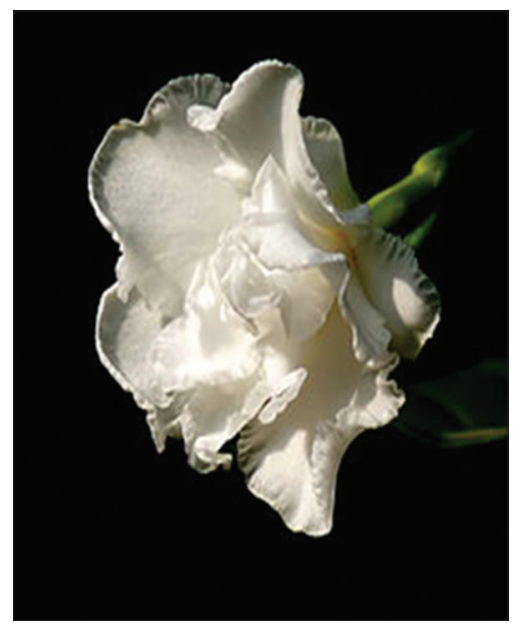

Figure 14: Pagiantha dichotoma

\section{Biological source}

Tabernaemontana is a genus of flowering plants.

Family: Apocynaceae.

\section{Chemical constituent}

The plant has been reported to contain a variety of alkaloids, including, in the bark of the stem and root: Tabernaemontanine, coronarine, coronaridine and dregamine. 


\section{Medicinal uses}

- The fruits are used in the treatment of ulcers and fistulae.

- The latex is used to soften and ripen boils and carbuncles.

- $\quad$ Pounded leaves and bark are externally applied on snake and centipede bites. A preparation of the bark is poulticed on grazed skin as an antiseptic and astringent.

\section{Toxic part}

All parts are toxic.

\section{Mode of action}

Mechanism of action on vasorelaxant activity of 10-methoxyaffinisine, cathafoline, and alstonisine was clarified. Effects of 10-methoxyaffinisine, cathafoline and alstonisine were partially mediated the NO release from endothelial cells. Furthermore, 10-methoxyaffinisine and alstonisine attribute to theinhibitory effect of VDC and ROC, and cathafoline have inhibitory effect on Ca2 influx via ROC.

\section{Herbal remedies}

- Treatment of poisoning Herbal remedies infusion of the roots is used as an antipyretic.

- Decoction is used as an astringent and anti-diarrheal.

- A preparation of the bark is poulticed on grazed skin as an antiseptic and astringent (Figure 14). ${ }^{[38]}$

\section{Dieffenbachia}

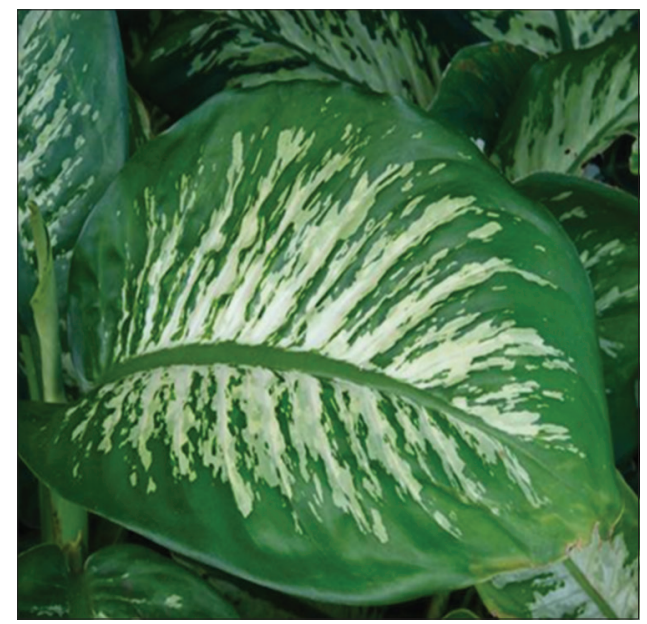

Figure 15: Dieffenbachia

\section{Biological source}

Dieffenbachia is a genus of tropical flowering plants.

Family: Araceae.

\section{Chemical constituent}

The major constituents in the leaf oil were pyrimidine-5-carboxylic acid, 4-(1, 3-dimethyl-1H-pyrazol-4-yl)-6-methyl-2-thioxo-1,2,3,4- tetrahydro-methyl ester (5.814\%), 5-methyl-2-phenylindolizine (2.957\%), 1-dicothine.

\section{Medicinal uses}

As a toxin to poison the arrows - the juice of the plant has been used by the native Amazonian people to be part of the preparations with which they poisoned the arrows.

\section{Mode of action}

- Many plants use oxalic acid, and/or its oxalate salts, to discourage insects and large animals from eating them.

- This leads us to the hope that osteoarthritis might be a long-term "organic" weapon for mite control.

\section{Treatment of poisoning}

- Wipe out the mouth with a cold, wet cloth. Rinse your eyes and skin well if they touched the plant. Give milk to drink.

- Intravenous fluids to maintain adequate hydration.

- Antihistamines, artificial respiration and oxygen, demulcents, epinephrine,

- Treat symptoms as they appear, supportive therapy.

\section{Herbal remedies}

Leaf decoction used as gargle for angina. Root tincture used for genital pruritus and gout (Figure 15). ${ }^{[39,40]}$

\section{Anthurium sp.}

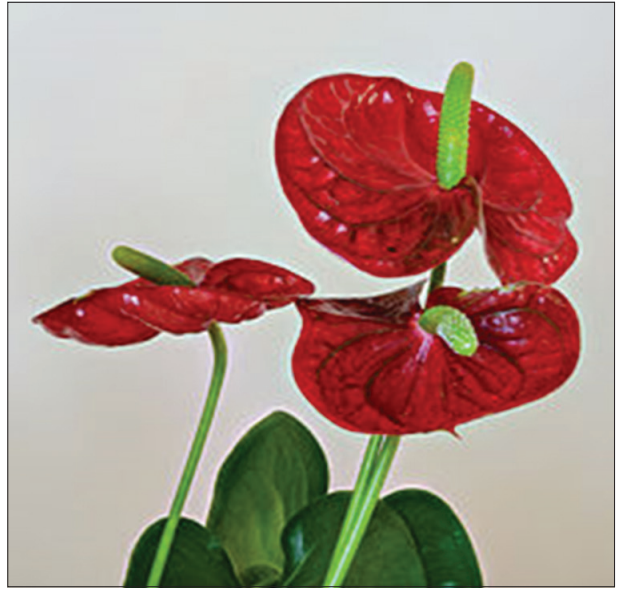

Figure 16: Anthurium sp.

\section{Biological source}

Anthurium is a genus of about 1000 species of flowering plants.

Family: Araceae.

\section{Chemical constituent}

Plant is found to be another source of ipecac alkaloids, viz., cephaeline, emetine, psychotrine. Root bark contains alangine A, alangicine 
marckine, marckidine, tubulosine, isotubulosine, cephaeline, emetine, psychotrine, demethylpsychotrine, and lamarckinine.

\section{Medical uses}

- Anthurim in stem for the discomforst of arthritis and rheumatism.

- The persone sweats and the medicinal properties enter in the body through open pores.

- It also useful as a poultice for muscle aches and cramps.

\section{Treatment of poisoning}

- Decontaminate mouth, eye, and skin by physically removing all plant material. Treat eye and skin exposure with copious water irrigation.

- Remove any plant material from the oral cavity. If airway compromise is ruled out, the patient may be allowed to drink cold liquids, eat crushed ice, or frozen desserts for relief.

- Oral swishing of diphenhydramine elixir may provide anesthetic and antihistamine effects.

\section{Herbal remedies}

- Use of anthurim in steam for the discomforts of arthritis and rheumatism. You cut up the leaves and boil it in a pot and have the person sit over it in a chair with a blanket. The person sweats and the medicinal properties enter the:

- It is also useful as a poultice for muscle aches and cramps (Figure 16). ${ }^{[41]}$

\section{Zantedeschia aethiopica}

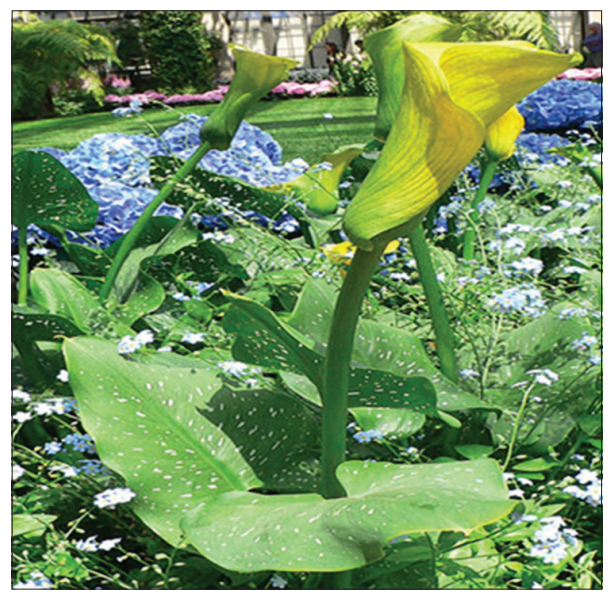

Figure 17: Zantedeschia aethiopica

\section{Biological source}

Z. aethiopica (Known as calllily and arum lily).

Family: Araceae.

\section{Chemical costituent}

The callus chemical composition was as follows: Total phenols (802.47 mg 100/g), starch (19.8 g 100/g), total soluble sugar
( $3.1 \mathrm{~g} 100 / \mathrm{g})$, reducing sugar $(1.2 \mathrm{~g} 100 / \mathrm{g})$, non-reducing sugar $(1.8 \mathrm{~g} 100 / \mathrm{g})$, ether extract $(1.0 \%)$, and protein $(20 \%)$.

\section{Medical uses}

- Leaves used as a dressing to treat wounds, sores and boils, or to treat rheumatism and gout.

- Boiled rhizomes mixed with honey have been used for bronchitis and asthma.

\section{Mode of action}

- Insoluble oxalate-containing plants have spindle-shaped cells named idioblasts containing needle-shaped crystals of calcium oxalate called raphides, 16 which may also be coated with a proteolytic enzyme.

- When the plant is crushed or chewed, the idioblasts are ruptured, and the sharp insoluble crystals and protease are injected into surrounding tissue structures such as the oral mucosa, tongue, and throat.

\section{Harbal remidies}

- Warmed leaves of Z. aethiopica are applied to sores, boils and insect bitesWarmed leaves are used to treat gout and rheumatism.

- A decoction of Zantedeschia albomaculata is used by Zulu women to prevent repeated miscarriages and giving birth to weak babies (Figure 17). ${ }^{[42-44]}$

\section{Cerbera manghas}

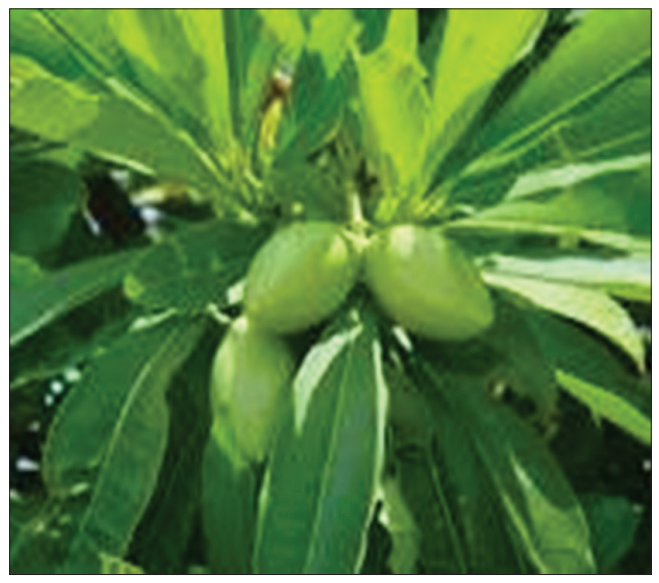

Figure 18: Cerbera manghas

\section{Biological source}

C. manghas (sea mango) is a small evergreen coastal tree growing up $12 \mathrm{~m}(39 \mathrm{ft})$ tall.

Family: Apocynaceae.

\section{Chemical constituents}

Chemical constituents were isolated by using various column chromatography and the structures were elucidated on the basis of physicochemical constants and spectral data analysis. 


\section{Medicinal uses}

- The seed oil in plasters applied to the skin is effective for scabies and prurigo, and applied to the hair kills head lice.

- The glycosides extracted from the seeds are active on heart failure.

- The trunk bark or the leaves are occasionally used as a purgative, but strict precautions must be taken because of their high toxicity.

\section{Mode of action}

- There is very little formal, modern published information on the mechanism of action of cerberin.

- Cerberin, as a cardiac glycoside, is seen as binding to and inhibiting the cellular $\mathrm{Na}+/ \mathrm{K}+$-ATPase, because it binds to the alpha-subunit of the enzyme.

- This is the catalytic moiety. There are also a beta- and FXYD subunits.

- These two subunits influence the affinity of cerberin to $\mathrm{Na}+/$ $\mathrm{K}+$-ATPase. The expression of the beta- and FXYD-subunit is tissue-specific.

\section{Treatment of poisoning}

Antitoxins developed against colchicine and cardiac glycosides would be useful for plant poisonings - anti-digoxin Fab fragments.

\section{Herbal remedies}

- The plant sap is used immediately for minor cuts.

- A decoction of the inner bark is drunk with cold water as an abortifacient (Figure 18). ${ }^{[45,46]}$

\section{Jatropha curcas}

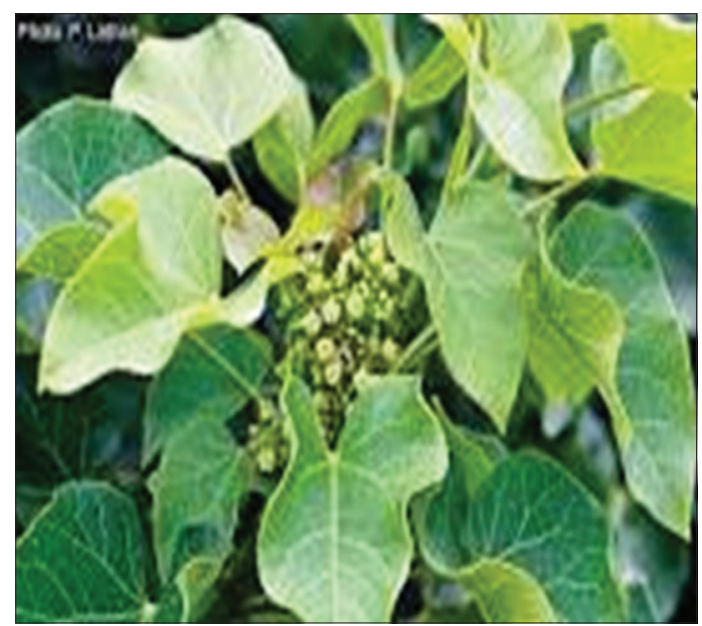

Figure 19: Jatropha curcas

\section{Biological source}

J. curcas is a species of flowering plant in the spurge.

Family: Euphorbiaceae.

\section{Chemical constituent}

Thirteen compounds were isolated from the roots of Datropha curcas L. Combining the determination of physicochemical constants and spectral analyses (IR, 1H-NMR, 13C-NMR, EIMS, FABMS), the structures of the compounds were identified as $5 \alpha$-stigmastane-3, 6-dione (1), nobiletin (2), $\beta$-sitosterol (3), taraxerol (4), 2S-tetracosanoic acid glyceride-1(5), 5-hydroxy-6,7dimethoxycoumarin (6), jatropholone A (7), jatropholone B (8).

\section{Medicinal uses}

Used as a purgative, antihelminthic and abortifacient as well as for treating ascites, gout, paralysis and skin diseases. The treatment of fever, jaundice, and gonorrhea, as a diuretic agent, and a mouth-wash.

\section{Mode of action}

- Phytotoxins (toxalbumins): It has been suggested that in vivo phytotoxins act as proteolytic enzymes, owing their toxicity to the breakdown of critical proteins and the accumulation of ammonia.

- Tetramethylpyrazine (TMPZ): Has been found to possess a nonspecific spasmolytic and vasodilator activity.

- These actions may account, at least in part, for the reported hypotensive (depressor) effects of the amide alkaloid in experimental animals.

\section{Herbal remedies}

- The seed oil of the plant has been used as an ingredient in the treatment of rheumatic conditions, itch and parasitic skin diseases, and in the treatment of fever, jaundice and gonorrhea, as a diuretic agent and a mouth-wash.

- The leaf has been used as a haemostatic agent and the bark as a fish poison.

- People are accustomed to chewing these seeds when in need of a laxative (Figure 19). ${ }^{[47,48]}$

\section{Jatropa multifida}

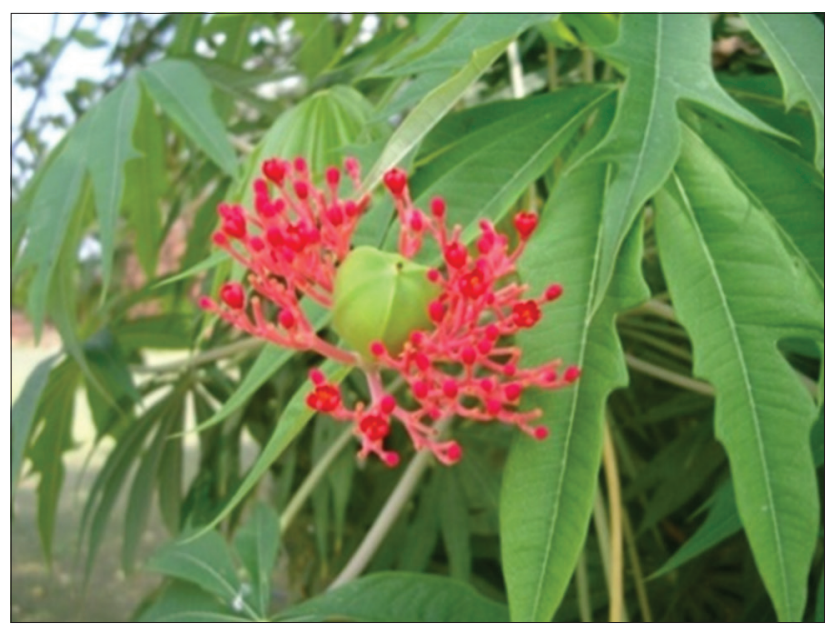

Figure 20: Jatropa multifida 


\section{Biological source}

Jatropha is a genus of flowering plants in the spurge.

Family: Euphorbiaceae.

\section{Chemical constituent}

Seeds contain $6 \%$ glucose, $1 \%$ bitter principle, and $30 \%$ fixed oil. The latter turns vermillon with sulfuric acid. Seed oil is similar to J.curcas.

\section{Medicinal uses}

- The seed oil is sometimes used as a cathartic although it may cause strong irritation and even poisoning.

- $\quad$ Seeds are used fresh as a purgative and emetic.

- A very powerful purgative, their use has been almost abandoned in traditional medicine.

\section{Mode of action}

- Phytotoxins (toxalbumins): It has been suggested that in vivo phytotoxins act as proteolytic enzymes, owing their toxicity to the breakdown of critical proteins and the accumulation of ammonia.

- TMPZ: Has been found to possess a non-specific spasmolytic and vasodilator activity.

- These actions may account, at least in part, for the reported hypotensive (depressor) effects of the amide alkaloid in experimental animals.

\section{Herbal remedies}

- The oil is applied both internally and externally as an abortificient.

- Seeds are used fresh as a purgative and emetic.

- The latex is used externally in the treatment of infected wounds, ulcers, skin infections and scabies.

- Dried roots are given as a decoction against indigestion and colic; they are also prescribed as a tonic to treat orchiti and oedemas.

- The seeds contain around 30\% of non-edible oil that can be used for illumination. (Figure 20). ${ }^{[49]}$

\section{Eucalyptus robusta}

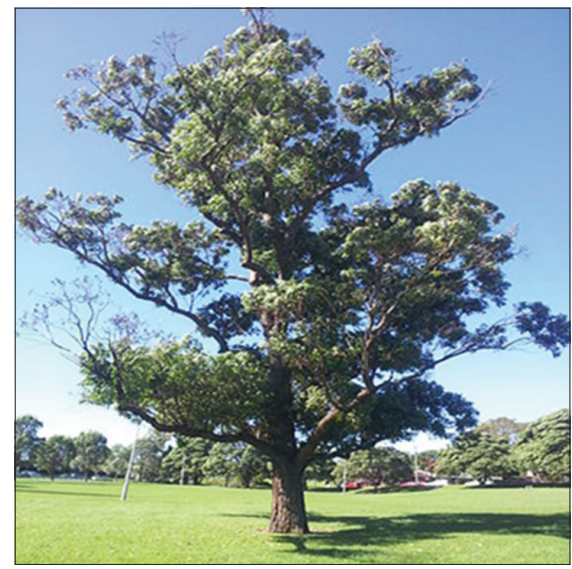

Figure 21: Eucalyptus robusta

\section{Biological source}

Eucalyptus is a diverse genus of flowering trees and shrubs.

Family: Myrtaceae.

\section{Chemical constituent}

The kino contains the antibiotic citriodorol. Leaves and fruits were positive for flavonoids, sterols, and tannins. The bark contains only $1.4 \%$ tannin.

\section{Medicinal uses}

- The essential oil has shown antibacterial and antifungal activity. Leaves have shown antioxidant activity.

- $\quad$ Phenolic compounds with activity against the malaria-inducing protozoan Plasmodium berghei have been isolated from the leaf.

\section{Treatment of poisoning}

The chemical is on the skin or in the eyes, flush with lots of water for at least $15 \mathrm{~min}$.

\section{Herbal remedies}

- An infusion of the leaves is used in both Africa and China for treatment of malarial fever.

- A decoction of the leaves is used in baths to treat stiffness, rheumatism and epilepsy.

- In Madagascar a handful of buds is rubbed and squeezed, and the sap is applied to the nostrils to relieve headache (Figure 21). ${ }^{[50]}$

\section{Daphne}

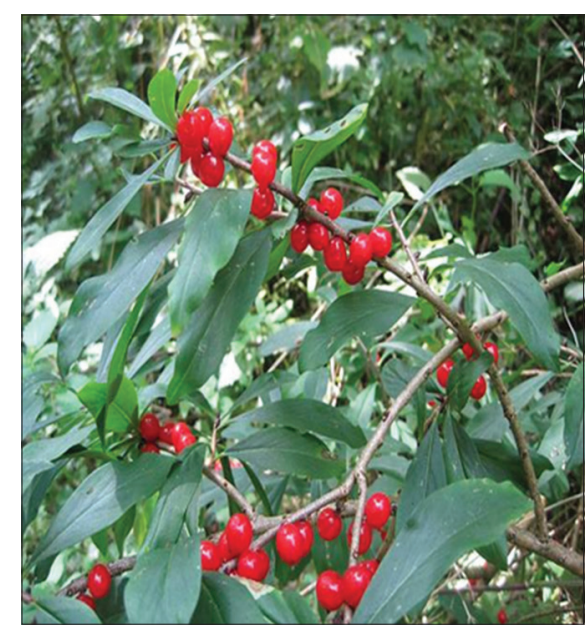

Figure 22: Daphne

\section{Biological source}

Daphne a genus of between 50 and 95 species of deciduous and evergreen shrubs.

Family: Thymelaeaceae. 


\section{Chemical constituent}

Sixteen compounds were obtained and nine of them were identified as beta-sitosterol, 4-hydroxy ethylbenzoate, (2E),-2-propenoic acid, 3-(3,4-dihydroxyphenyl)-decosylester, genkwanin.

\section{Medicinal uses}

- The flowers and the stems are anodyne, antiphlogistic, antispasmodic, depurative, and ophthalmic.

- A decoction is used in the treatment of backache, myalgia, skin diseases, poor vision etc. A decoction of the leaves is used in the treatment of laryngitis and sore throats.

- A decoction of the roots and leaves is used in the treatment of sore throat and caked breast.

\section{Mode of action}

- Modes of action to prevent building up resistant fungal populations. Use fungicides as preventative treatments.

- The Group 4 and 33 fungicides used to manage Phytophthora do not kill this organism.

- They can only prevent establishment of the organism before it gets into the plant.

- They can also prevent continued growth if the organism is already inside the plant thereby delaying symptoms that might have developed.

- Once chemical activity has subsided with time, the organism can resume growth within infected plants.

\section{Treatment of poisoning}

- Demulcents

- A gastric lavage and emesis

- Treat symptoms as they appear, supportive therapy.

\section{Herbal remedies}

- The Lebanese put berries or leaves in brandy, which they left in the sun for a couple of days. They believed that this mixture helped them mitigate stomach pains.

- Daphne also possessed emetic qualities which triggered vomiting.

- Recommended daphne leaf poultice as a way to cure wounds and recent research revealed that this medical approach is quite effective (Figure 22). ${ }^{[30]}$

\section{Nerium oleander}

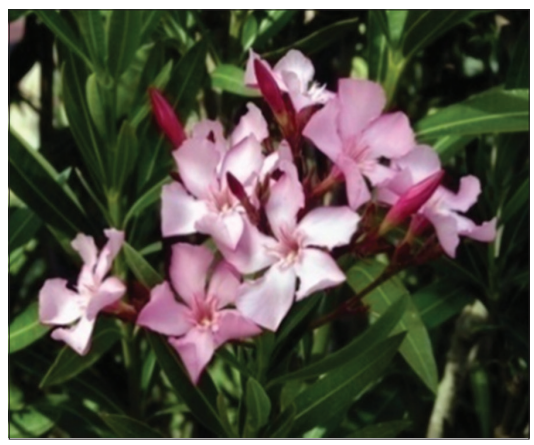

Figure 23: Nerium oleander

\section{Biological source}

It obtain $N$. oleander is an evergreen shrub or small tree in the dogbane.

Family: Apocynaceae.

\section{Chemical constituents}

The acrid and bitter leaves of N. oleander contain, three glucosids, namelyon-basic, amorphous, alkaloid like nerein (neriin).

\section{Medicinal uses}

- Oleander has been used in the treatment of cardiac illness, asthma, diabetes mellitus, corns, scabies, cancer, and epilepsy.

- Oleandrin inhibits certain kinases, transcription factors and inflammatory mediators.

\section{Mode of action}

- Cardenolides inhibit normal function in the myocardium and cardiac conducting tissue.

- A major mechanism is their inhibition of membrane-bound sodium-potassium-ATPase, which normally exchanges extracellular potassium for intracellular sodium.

- Inhibition causes decreased active transport of potassium into, and sodium out of, myocardial cells, producing hyperkalaemia and increased intracellular sodium concentrations.

- The latter reduces the activity of the sodium-calcium exchange mechanism, which normally transfers calcium out of the cell in exchange for sodium.

\section{Treatment of poisoning}

Antitoxins developed against colchicine and cardiac glycosides would be useful for plant poisonings - anti-digoxin Fab fragments have been shown to be highly effective.

\section{Herbal remedies}

- Usefulness in increasing healing times for wounds, when crushed and applied topically

- Help for skin conditions such as eczema (Figure 23). ${ }^{[51]}$

\section{Atropa belladonna}

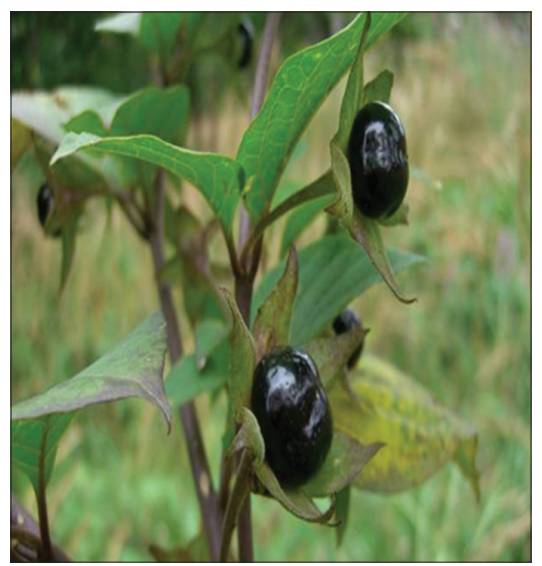

Figure 24: Atropa belladonna 


\section{Biological source}

A. belladonna is a perennial herb, with a thick, branched, fleshy, creeping root, and annual, erect, round, dichotomously branched, leafy, slightly downy stems, about 3 feet high.

Family: Solanaceae.

\section{Medicinal uses}

Belladonna has been used in herbal medicine for centuries as a pain reliever, muscle relaxer, and anti-inflammatory, and to treat menstrual problems, peptic ulcer disease, histaminic reaction, and motion sickness.

\section{Chemical constituent}

The main constituents of belladonna are as follows: Atropine and hyoscyamine.

\section{Mode of action}

- Pharmaceutical textbooks state that belladonna alkaloids are competitive inhibitors of the muscarinic actions of acetylcholine, acting at receptors located in exocrine glands, smooth and cardiac muscle, and intramural neurons.

- The belladonna constituent scopolamine exerts greater effects on the CNS, eye, and secretory glands than the constituent's atropine and hyoscyamine.

- Atropine exerts more activity on the heart, intestine, and bronchial muscle, and exhibits a more prolonged duration of action compared to scopolamine.

- Hyoscyamine exerts similar actions to atropine but has more potent central and peripheral nervous system effects.

\section{Treatment of poisoning}

- Give prompt emetic and then reliance must be placed on continual stimulation with brandy, whisky, etc., and to necessary artificial respiration. Opium and its preparations, as morphia, laudanum, etc.

- May be given in small and repeated doses, as also strong black coffee and green tea.

\section{Herbal remedies}

- The leaves are employed as an ingredient of cigarettes for relieving asthma.

- Belladonna plasters are applied to the injured or sprained part and is also recommended as an application for corns and bunions.

- Belladonna is also used in homeopathic treatment and to relieve headaches caused by tension (Figure 24). ${ }^{[51-53]}$

\section{Acokanthera spectabilis}

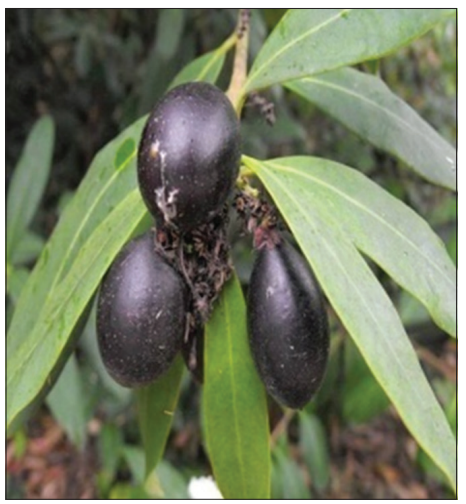

Figure 25: Acokanthera

\section{Biological source}

Acokanthera is a genus of flowering plants.

Family: Apocynaceae.

\section{Chemical constituent}

The major compounds of Cinnamomum mercadoi were safrole (30.3\%), 1,8-cineol (29.4\%) and eugenol (15.4\%) whereas Cinnamomum mindanaense contained eugenol (39.2\%), linalool (19.4\%), safrole (15.0\%) and 1,8-cineol (12.8\%).

\section{Medicinal uses}

- Very poisonous, the plant is used locally in Africa, especially to treat snakebites and as an emetic.

- Numerous cardenolides have been detected in the wood, leaves, seeds and fruit, the most important being acovenosides $\mathrm{A}$ and $\mathrm{B}$, which both have cardio-vascular properties. Other cardenolides that were isolated are acovenoside $\mathrm{C}$, spectabiline and acopieroside II.

\section{Mode of action}

- Ouabain is a cardiac glycoside that acts by inhibiting the $\mathrm{Na}+/$ $\mathrm{K}+$-ATPase sodium-potassium ion pump.

- Once ouabain binds to this enzyme, the enzyme ceases to function, leading to an increase of intracellular sodium.

\section{Treatment of poisoning}

- Atropine

- Phenytoin.

\section{Herbal remedies}

- To treat snakebites and spider bites, a small amount of the leaves is eaten, a leaf or root decoction is drunk and the leaf or root pulp is rubbed into the wound. 
- Root powder is sniffed and a dressing made of roots or leaves is put on the swollen part. A root infusion is taken to treat syphilis.

- Root powder or leaf powder is sniffed to cure headache, while a leaf infusion is used as a nasal spray for this purpose.

- Small pieces of the stem are chewed against toothache.

- A leaf infusion is taken to treat abdominal pain, colds, measles and blood poisoning.

- A root infusion is taken to expel tapeworm and to treat excessive and irregular menstruation (Figure 25). ${ }^{[31,33]}$

\section{Solanum nigrum}

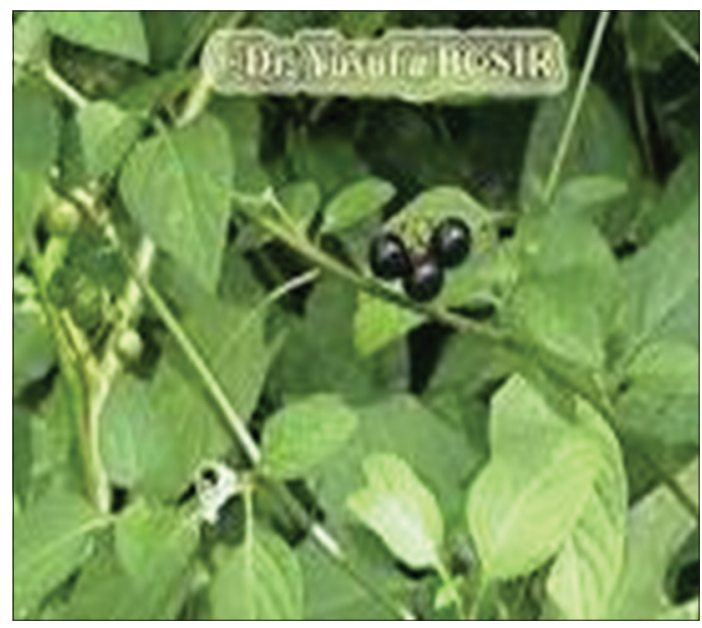

Figure 26: Solanum nigrum

\section{Biological source}

S. nigrum or locally just black nightshade, duscle, garden nightshade, garden huckleberry, hound's berry, petty morel, wonder berry, smallfruited black nightshade, or popolo) is a species in the Solanum genus.

Family: Solanaceae.

\section{Chemical constituent}

Major active components are glycoalkaloids, glycoproteins, and polysaccharides. It also contains polyphenolic compounds such as gallic acid, catechin.

\section{Medicinal uses}

It has expectorant, analgesic, sedative, diaphoretic properties. It is external application cures skin diseases and gives relief in burns, itching, pain etc.

\section{Mode of action}

- The toxic mechanism of solanine is not well described. In vitro studies have suggested that solanine is reversible inhibitors of human acetylcholinesterase and pseudo or butyroyl cholinesterase.

- Uncertain relevance as solanine toxicity is not typically associated with classic cholinergic symptoms.

- $\quad$ Reflect competing effects at nicotinic and muscarinic sites.
Table 3: List of importance poisonous plants with B.S, local name, family and part use

\begin{tabular}{|c|c|c|c|}
\hline Scientific name & Local name & Family & $\begin{array}{l}\text { Poisonous } \\
\text { parts }\end{array}$ \\
\hline Thevetia peruviana & Yellow oleander & Apocynaeae & All parts \\
\hline Datura metel & Kachubung & Solanaceae & All parts \\
\hline Abrus precatorius & Rosary pea & Fabaceae & Seeds \\
\hline Myristica fragrans & Nutmeg & Myristicaceae & Seeds \\
\hline Strychnos nux-vomica & Nux-vomica & Loganiaceae & Seeds \\
\hline Alocasia macrorrhiza & Giant taro & Araceae & Stem, leaves \\
\hline Glorisa superb & Gloriosa simplex & Colchicaceae & All parts \\
\hline Ricinus communis & Castor bean & Ephorbiaceae & Seeds \\
\hline Manihot utilissima & Cassava & Ephorbiaceae & Leaves, seeds \\
\hline Peganum harmala & Harmala & Nitrariaceae & All parts \\
\hline Adenia palmate & Chinese abelia & Passifloraceae & All parts \\
\hline Nicotiana tabacum & Petume & Solanaceae & Seeds \\
\hline Pagiantha dichotoma & Poison nut & Apocynaceae & All parts \\
\hline Dieffenbachia & Dumb cane & Araceae & All parts \\
\hline Anthurium sp. & Strepsanthera Raf. & Araceae & All parts \\
\hline Zantedeschia aethiopica & Hauttunia neck & Araceae & All parts \\
\hline Cerbera manghas & Pong-pong & Apocynaceae & Seeds \\
\hline Jatropha curcas & Barbados nut & Euphorbiaceae & All parts \\
\hline Jatropha multifida & $\begin{array}{l}\text { Adenorhopium } \\
\text { Rchb }\end{array}$ & Euphorbiaceae & All parts \\
\hline Eucalyptus robusta & $\begin{array}{l}\text { Eucalyptus } \\
\text { multiflora Poir }\end{array}$ & Myrtaceae & All parts \\
\hline Amanita phalloides & Death cap & Amanitaceae & All parts \\
\hline Daphne & Daphne indica & Thymelaeaceae & All parts \\
\hline Nerium oleander & Oleander medik & Apocynaceae & All parts \\
\hline Atropa belladonna & Atropine & Solanaceae & All parts \\
\hline Cicuta maculate & Cicuta bolanderi & Apiaceae & All parts \\
\hline Acokanthera spectabilis & Wintersweet & Apocynaceae & All parts \\
\hline Solanum nigrum & Black night shade & Solanaceae & All parts \\
\hline
\end{tabular}

\section{Treatment of poisoning}

- Induce vomiting if it hasn't already occurred.

- Lavage, activated charcoal and supportive therapy.

- Decontamination, supportive the rapy livestock, deer, and humans are susceptible.

- $\quad$ Paraldehyde (2-10 cc) IM.

\section{Herbal remedies}

- The Arabs used the bruised fresh leaves to erase pain and reduce inflammation. They also applied the poultice of the leaves to burns and considered it good for ulcers.

- It is very good for mouth sores and ulcers. Make a juice with the leaves and gargle with it. Also chewing some leaves and keeping it in your mouth for sometime helps to heal mouth ulcers.

- It is a diuretic and hence helps in the discharge of urine. A decoction made from the leaves and stem of the plant helps this purpose.

- The leaves of the Solanum nigrum is a natural home remedy to treat digestive problems. The juice of the leaves is good for 
flatulence, peptic ulcers, and dysentery. An infusion of the plant is good for abdominal upsets (Figure 26). ${ }^{[54]}$

\section{Conclusion}

The study concludes that toxic medicinal plants have some medicinal values. Certain precautions about those plants are enough to use these toxic plants as medication purpose. Since plant toxins show many useful effects, they can be used in treating respective diseases. They can be modified to show better affinity and efficacy. Poisonous medicinal plants are used for various ailments. This study reveals that wide numbers of phytochemical constituents have been reported from various medicinal plants which possess pharmacological activities, herbal remedies, and other important medicinal properties (Table 3). This information is most important for pharmaceutical companies could formulate drug.

\section{References}

1. Huxley A. New RHS Dictionary of Gardening Macmillan. Available from: https://www.amazon.co.uk/New-RHS-Dictionary-Gardening-Volumes/ dp/1561592404 1992

2. Gloriosa superba. Pacific Island Ecosystem at Risk (PIER). Available from: http://www.hear.org/pier. [Last accessed on 2016 Dec 06].

3. Priya VK, Gopalan R. A survey on some poisonous plants and their medicinal values in Dhoni forest, Palakkad, Kerala, India. Int J Curr Microbiol Appl Sci 2015;4:234-9.

4. Parikh CA. Parikh's Text Book of Medical Jurisprudence and Toxicology. $5^{\text {th }}$ ed. Shadara, Delhi: C.B.S Publishers; 1990. p. 235-8.

5. Myristica fragrans Houttu, Germplasm Resources Information Network (GRIN) Online Database. 2016 Dec 08. Available fromttps://www.en. wikipedia.org/ wiki/Myristica_fragrans. [Last retrieved on 2014 Dec 06-07].

6. Camovic TA, Stewart CS, Pennycott TW. Poisonous Plants and Related Toxins. USA: CABI Publishers; 2004. p. 1, 7, 38, 151.

7. Strychnos nux - Vomica. Natural Resources Conservation Service Plant Database. USDA. Available from: http://www.plants.usda.gov/java/. [Last retrieved on 2015 Dec 04].

8. Langford SD, Boor BJ. Oleander toxicity: An examination of human and animal toxic exposure. Toxicology 1996;109:1-13.

9. USAD GRINTaxonomy. Available from: https://www.ars.usda.gov/research/ publications/publication/?seqNo115 $=60735$. [Last retrieved on 2014 Feb 04].

10. Available from: http://www.plantzafrica.com/plantwxyz/zantedeschaeth. htm. [Last accessed on 2016 Nov 12].

11. Shibamoto T, Bjeldanes LF. Introduction to Food Toxicology. $1^{\text {st }}$ ed. California: Academic Press; 1993. p. 123-63.

12. John M. Cote Ce Cote La: Trinidad and Tobago Dictionary. Arima, Trinidad. Available from: http://www.worldcat.org/title/cote-ce-cote-la-trinidadand-tobago-dictionary $/$ oclc $/ 58957376 /$ editions? $r e f e r e r=$ di\&editions View $=\mathrm{t}$ rue. [Last accessed on 2016 Dec 05].

13. Peganum harmala Information from NPGS/GRIN. Available from: https:// www.npgsweb.ars-grin.gov/gringlobal/taxonomydetail.aspx?27098. [Last retrieved on 2008 Feb 17].

14. Newton LE. Etymological Dictionary of Succulent Plants Names. Vol. 8. Berlin: Springer Verlag; 2001, 2004.

15. Available from: http://www.museum.gov.ns.ca/poison/default. asp?section $=$ list. [Last retrieved on 2010 Apr 03].

16. Concon JM. Food Science and Toxicology. Part A Principles and Concepts. $1^{\text {st }}$ ed. New York: Marcel Dekker; 1988 . p. 120-2.

17. Reddy KS. Medical Jurisprudence and Toxicology (Law Practice Procedure). $1^{\text {st }}$ ed. Hyderabad: ALT Publications; 2005. p. 109-12.

18. Wagstaff DJ. International Poisonous Plants Check List. New York: An Evidence Based Reference, CRC Press; 2008. p. 1-25, 235-71.

20. Available from: http://www.ansci.cornell.edu/plants/toxicagents/tannin. html. [Last retrieved on 2010 Mar 15].

21. Ulrike P, Hans-Georg P. Brugmansia and Datura: Angel's Trumpets and Thron Apples. Buffalo. $1^{\text {st }}$ ed. New York: Firely Book; 2002. p. 120-3.

22. Jatropha curcas L. Germplasm Resources Information Network United States Department of Agriculture. Available from: http://www.ars-grin.gov. 2010. p. 10-14. [Last retrieved on 2008 Aug 29].

23. Jatropha curcas L. Euphorbiaceae. Agroforesree Database 4.0. World Agroforrestry Centre. Available from: http://www.worldagroforestry. org/treedb/AFTPDFS/Jatropha_curcas.PDF. 2009. [Last retrieved on 2010 Oct 14].

24. Jatropha. Natural Resources Conservation Service Plant Database. USDA. Available from: https://www.en.wikipedia.org/wiki/Jatropha. [Last retrieved on 2015 May 27].

25. Foster PI. A taxonomic revision of Cerbera L. In Australia and papuasia. Austrobaileya 1992;3:569-79.

26. World Checklist of Seleted Plant Families. Available from: http://www.kew. org $/$ wcsp $/$ qsearch.do?plantName $=$ mShirakiopsis $\&$ page $=$ quickSearch. [Last retrieved on 2014 May 21].

27. Hearn DJ. Adenia (Passifloraceae) and its adaptive radition: Phylogeny and growth form diversification. Syst Bot 2006;31:805-21.

28. Genus: Jatropha L. Germplasm Resources Information Network United States Department of Agriculture. Available from: http://www.ars-grin.gov/200710-05. [Last retrieved on 2010 Aug 13].

29. Eucalyptus robusta Sm. Australian Plant Name Index (APN), IBIS Database Centre for Plant Biodiversity Research, Australian Government. Available from: https://www.en.wikipedia.org/wiki/Eucalyptus_tereticornis. [Last accessed on 2016 Dec 12].

30. Beckett K, editors. Encyclopaedia of Alpines. Vol. 1. Pershore, UK: AGS Publications; 1993. p. 371-6.

31. Cicuta maculata Information from NPGS/GRIN. Available from: http://www. ars-grin.gov. [Last accessed on 2016 Oct 11].

32. Sunset Books. Sunset Western Garden Book. $9^{\text {th }}$ ed. Revised and Updated. Mexico: Leisure Arts; 1995. p. 606-7.

33. Acokanthera oblongifolia. The Plant List. Available from: http://www.the plantlist.org/browse/A/Gentianaceae/Anthocleista. [Last retrieved on 2013 Jul 22].

34. Arnold HL. Poisonous Plants of Hawaii Tokyo, Japan: Charles E. Tuttle. Available from: http://www.thepharmajournal.com/archives/2015/ vol4issue 5/PartB/4-4-27.pdf. [Last accessed on 2016 Dec 06].

35. Seawright AA. Directly toxic effects of plant chemicals which may occur in human and animal foods. Nat Toxins 1995;3:227-32.

36. Alocasia Macrorrhizos (L.) G. Don.Germsplasm Resources Information Network. United States Department of Agriculture. 2016 Dec 2. Available from: http://www.wikivisually.com/wiki/Arum_montanum. [Last retrieved on 2010 May 23].

37. Altug T. Introduction to Toxicology and Food. 1 $^{\text {st }}$ ed. UK: CRC Press; 2002. p. $39-71$.

38. Govaerts R, Frodin DG. World Chechlist and Bibliogaraphy of Araceae, the Board ofTrustees of the Royal Botanic Gardens; 2002. p. 1-560. Available from: http://www.apps.kew.org/wcsp Kew.

39. D'Mello JP. Handbook of Plant and Fungal Toxicants. UK: CRC Press; 1997. p. 19, 63, 157, 191, 205.

40. Duke JA. Ethnobotanical Uses. Germplasm Resources Information Network: Dr. Duke's Phytochemical and Ethnobotanical Databases. USDA. [Last retrieved on 2012 Jun 09].

41. Myristica fragrans Houttu. Flora of China. 2016 Nov 6. Available from: http://www.wikivisually.com/wiki/Myristica_fragrans. [Last retrieved on 
2014 Nov 06-07].

42. Haborne JB, Baxter H, Moss JP. Dictionary of Plant Toxins. Vol. 1. USA: Wiley Chichester; 1996. p. 95.

43. World Checklist of Selected Plant Families, entry for Nerium oleander. Available from: http: //www.apps.kew.org/wcsp. [Last retrieved on 2014 May 18].

44. Acokanthera oblongifolia. Available from: http://www.the plantlist.org/ browse/A/Gentianaceae/Anthocleista/Encyclopedia of Life. [Last retrieved on 2013 Jul 22].

45. Greval SD. Lyon's Medical Jurisprudence for India. $10^{\text {th }}$ ed. Calcutta, India: Thacker, Spink \& Co. Ltd.; 1953. p. 203-4.

46. Mantivani A, Pereira TE. Anthurium (section urospadix subsection Flavescentiviridia). Rodriguesia 2005;56:145-60.

47. Gloriosa superba. Germplasm Resources Information Network. Available from: http: //www.ars-grin.gov. [Last accessed on 2016 Dec 07].

48. Cassava. Food and Agriculture Organization of the United Nations. Available from: http: //www.fao.org/3/a-i3278e.pdf. [Last accessed 2016 Dec 02].
49. WCSP. Word Checklist of Selected Plant Families. Available from: http:// www.apps.kew.org/wcsp/prepareChecklist.do?checklist=selected_ families\%40\%40349141220160504316. [Last accessed on 2010 Jun 30].

50. Albert H, Evans R. Plants of Gods: Origins of Hallucinogenic Use. $1^{\text {st }}$ ed. New York: Van der Marck; 1987. p. 88.

51. Bhatt AK. Poisonous Plants of India. Available from: http://www.sawf.org/ newedit/edit. [Last accessed on 2009 May 01].

52. Ren N, Timko MP. AFLP analysis of genetic polymorphism and evolutionary relationships among cultivated and wild Nicotiana species. Genome 2001;44:559-71.

53. WCSP (2013). World Checklist of selected Plant families. Available from: https://www.en.wikipedia.org/wiki/World_Checklist_of_Selected_Plant_ Families Facilitated by the Royal Botanic Garden, Kew. [Last retrieved on 2013 Oct 06].

54. Ricinus communis. Natural Resources Conservation Service Plants Database. Available from: http://www.issg.org/database/species/references.asp?si=10 $00 \& \mathrm{fr}=1 \&$ sts $=$ tss\&lang $=$ TC USDA. [Last retrieved on 2016 Feb 01]. 